(RESEARCH ARTICLE)

\title{
Bio-control of Vibrio species in cultured milk by in situ bacteriocin production from lactic acid bacteria
}

Ogunbanwo Samuel Temitope ${ }^{1}$, Odubanjo Oluwadamilola Rashidat ${ }^{1}$, Adegoke Caleb Oladele ${ }^{2, *}$ and Oramadike Chigozie ${ }^{3}$

\author{
${ }^{1}$ Department of Microbiology, University of Ibadan, Oyo State, Nigeria. \\ 2 Ogun State College of Health Technology, Ilese Ijebu, Department of Medical Laboratory Science P.M.B. 2081. \\ ${ }^{3}$ Fish Technology Department, Nigerian Institute for Oceanography and marine Research, P. M. B.12729, Victoria Island \\ Lagos, Nigeria.
}

Publication history: Received on 22 March 2020; revised on 12 June 2020; accepted on 14 June 2020

Article DOI: https://doi.org/10.30574/wjarr.2020.6.3.0073

\begin{abstract}
The growth of resistance to antibiotic by Vibrio signifies a possible risk to human health; hence, there is a need to deploy another technique for controlling species of Vibrio. This study was undertaken to demonstrate the antagonistic activity of bacteriocin-producing Lactic acid bacteria against Vibrio alginolyticus, Vibrio vulnificus, Vibrio harveyi, Vibrio parahaemolyticus, Vibrio fluvialis, and Vibrio cholera in vitro and in situ. Lactic acid bacteria (LAB) were isolated from milk products and identified phenotypically. They were initially screened for antagonistic activity against the Vibrio species by the agar well diffusion assay, bacteriocins produced by the LAB were characterized with respect to $\mathrm{pH}$, enzymes and temperatures. The effect of in situ bacteriocin production by LAB on the survival of Vibrio species was determined in Nono, after fermentation of milk during the storage period of $72 \mathrm{~h}$ (12 h interval). Of the 112 strains of LAB tested for antagonistic activity against Vibrio species, only twelve were selected based on the bacteriocin production and large zone of inhibition against Vibrio species. They were characterised phenotypically and identified to be Pediococcus damnosus, Pediococcus acidilactici, Lactobacillus brevis and Lactobacillus plantarum. The bacteriocins produced by the $\mathrm{LAB}$ were heat stable at $90^{\circ} \mathrm{C}$ for $20 \mathrm{~min}$, active over a wide pH range (2 to 6), stable in the present of catalase but lost their activity in the present of proteolytic enzymes. Bacteriocins produced by the LAB showed antagonistic activity against Vibrio species with zones of inhibition ranges from 12 to $20 \mathrm{~mm}$. Vibrio species counts were reduced significantly to different extents in all samples of Nono and undetectable within 48 to 60 hours of Nono storage. On the contrary, Vibrio species survived for $72 \mathrm{~h}$ of storage in the control experiment that lack bacteriocin producing LAB. This work demonstrates that the use of selected bacteriocin-producing starter in milk fermentation might contribute to safety of dairy products.
\end{abstract}

Keywords: Lactic acid bacteria; Vibro species; Biocontrol; Fermentation; in situ Bacteriocins; production in Milk.

\section{Introduction}

Lactic Acid Bacteria are gram-positive, catalase negative, usually non-motile, non-spore-forming rods and cocci which produce lactic acid as the major end product of carbohydrate fermentation [1]. They cannot generate ATP because they lack the ability to synthesize cytochromes and porphyrins which are components of respiratory chains. They can only obtain ATP by fermentation, usually from sugars. They are facultative anaerobes and are protected from oxygen byproducts (e.g. $\mathrm{H}_{2} \mathrm{O}_{2}$ ) because they possess peroxidases [2]. Lactic Acid Bacteria are usually found in the environment related with rich nutrients, such as different food products (milk, meat, vegetables), although some of their members are of the flora of the intestine, mouth and vagina of mammals [3; 4]. One of the most important and significant values of lactic acid bacteria to humans is their beneficial role in health and inhibition of pathogenic bacteria. Some LAB are reputed to act directly as probiotics when ingested or incorporated into food products [5], or indirectly by action of the

\footnotetext{
${ }^{*}$ Corresponding author: Adegoke Caleb Oladele
} 
antimicrobial substances they produce in foods. Several antimicrobial substances are produced by various starter cultures of $\mathrm{LAB}$, which include organic acids, hydrogen peroxide, $\mathrm{CO}_{2}$, diacetyl and bacteriocins [6] which have received increasing attention during the past two decades.

Bacteriocins are definitely regarded as antimicrobial peptides that are produced from their ribosomes (ribosomally) which are active against other bacteria, either of the same species or across genera $[7 ; 8]$. They may be produced by both Gram negative and Gram positive bacteria [9]. In recent years, bacteriocin producing LAB have attracted significant attention due to their Generally Recognized as Safe (GRAS) status and potential use as safe additives for preservation of food [10] . Bacteriocins have potent antagonistic effect against important clinical pathogens as observed by [11]. Different types of bacteriocins from food-associated lactic acid bacteria have been characterised and identified, of which the important ones are nisin, diplococcin, acidophilin, bulgarican, helveticins, lactacins, and plantaricins [12]. Quite a lot of studies showed that LAB starter cultures or co-cultures are able to produce bacteriocins in food media, and as a result exhibited inhibitory potentials towards labile foods capable of spoilage or pathogenic bacteria. The genus Vibrio is oxidase-positive, Gram-negative, rod or curved shaped and facultative anaerobes that are motile, which produces cholera enterotoxin. They are responsible for food-borne disease, morbidity, life threatening and mortality [13; 14]. Several foods include vegetables, fruits, dairy products, sea foods, poultry, milk, meat products and others can become contaminated with Vibrio species as a result of improper handling, undercooking, washing with unhygienic water and by the use of untreated soil $[15 ; 16]$. These organisms are capable of producing a thermostable toxin known as hemolysin.

The principal cause of mortality in the developed, developing and the rest of the world is the Vibro vulnificus because of its association with sea food consumption [17]. However, the use of antibiotics in regulating Vibrio species is not encouraging as a result of the growth of antibiotic-resistance and the negative impact of antibiotic consumption on the host. An efficient microbiological protection and safety of milk is vital to ensure its purity and to avoid adverse human heath implication. However, research in this area has not been fully explored, therefore, the focus of this work centered on the testing of Lactic Acid Bacteria against multiple-drug resistance Vibrio species in milk and its products.

\section{Material and methods}

\subsection{Sample collection}

Samples of milk products ("Nono", "Wara" and Yoghurt) used in this study were obtained from local markets in Ibadan, Oyo State. Two replicate samples were collected and transported to the laboratory in sterile bottles. The samples were refrigerated at $4^{\circ} \mathrm{C}$ and analyzed within 24 hours of collection [18]. The multidrug resistance Vibrio species used as indicator organisms in this work had been previously phenotypic and molecular characterised as reported by [19].

\subsection{Sterilization}

All media were sterilized in an autoclave at $121^{\circ} \mathrm{C}$ for 15 minutes, except otherwise stated. Used glass wares were soaked in solutions containing antiseptic (Jik) overnight. They were then washed with liquid soap and rinsed in several changes of tap water. The glass wares were arranged on the drain board to drip off.

\subsection{Isolation procedure}

One $\mathrm{mL} / 1 \mathrm{~g}$ of the samples was homogenized with $9 \mathrm{ml}$ of sterile distilled water to make an initial dilution $10^{-1}$. The suspensions were used for making suitable serial dilutions up to $10^{-6}$ by incorporating $1 \mathrm{ml}$ into $9 \mathrm{ml}$ of sterile distilled water in sterile tubes. Using different sterile $1.0 \mathrm{ml}$ pipette, $0.1 \mathrm{ml}$ of $10^{-4}$ and $10^{-6}$ dilutions of the various samples were plated out.

\subsection{Culture preservation}

The isolates of Lactic acid bacteria were sub-cultured onto maintenance medium consisting of MRS broth with $12 \%$ (v/v) glycerol and incubated at $30^{\circ} \mathrm{C}$ until growth becomes visible. The stock cultures were stored at $4^{\circ} \mathrm{C}$ for subsequent use for a period of 2 to 4 weeks before sub-culturing into fresh medium. Vibrio species was stored in Tryptone Soy broth (TSB) and maintained at room temperature for further studies.

\subsection{Characterization of isolates}

This was carried out by employing macroscopic, microscopic and biochemical tests (all Gram positive, catalase negative and non-spores forming isolates were selected for sugar fermentation test). 
Ogunbanwo et al. / World Journal of Advanced Research and Reviews, 2020, 06(03), 050-058

\subsection{Identification of Isolates}

The isolates were identified based on the results of the various biochemical tests using Bergey's Manual of Systematic Bacteriology [20].

\subsection{Antimicrobial activity of bacteriocin producing LAB}

The agar diffusion assay described by [21]. Freshly prepared Vibrio species were used for this assay. One (1) ml of the indicator organism (Vibrio species) was inoculated into $15 \mathrm{ml}$ of semisolid Mueller Hinton agar (MHA plus $0.75 \%$ bacteriological agar) and then poured into a petri dish. After solidification, three wells (7 mm diameter) were cut and $50 \mu \mathrm{l}$ of cell-free supernatant (CFS) from each LAB isolate were added to each well. Cell-free supernatant was prepared as follows; one ml of frozen LAB isolate was cultured overnight in $20 \mathrm{ml}$ MRS broth, then $1 \mathrm{ml}$ culture was sub-cultured for 72 hours in $20 \mathrm{ml}$ MRS broth. Cells were removed by centrifuging at 14,000 g for 5 mins and $50 \mu$ l of the unadjusted aliquot of cell-free supernatant was added to the wells. . The plates were incubated at $37^{\circ} \mathrm{C}$ aerobically for $24 \mathrm{~h}$. Inhibition zones were measured and recorded appropriately.

\subsection{Characterization of bacteriocins produced by LAB}

\subsubsection{Treatment of antimicrobial compounds with NaOH and catalase enzyme}

The isolates that exhibited antagonistic activity against the pathogenic organism were investigated for their antimicrobial compounds using a modified method of [22]. The cell-free supernatant was adjusted to pH $6.0 \mathrm{with} 1 \mathrm{~mol}$ $\mathrm{l}^{-1} \mathrm{NaOH}$ in order to rule out possible inhibition effects due to organic acids. $50 \mu \mathrm{l}$ of the $\mathrm{pH}$ adjusted cell-free supernatant were filtered $(0.2 \mu \mathrm{m}$ pore-size cellulose acetate filter) and added to the second well. The neutralized cell-free supernatant was then treated with $1 \mathrm{mg} \mathrm{ml}-1$ of catalase at $25^{\circ} \mathrm{C}$ for $30 \mathrm{~min}$ to eliminate the possible inhibitory action of $\mathrm{H}_{2} \mathrm{O}_{2}$ and then was placed in the third well. The Mueller Hinton plates were incubated at $37^{\circ} \mathrm{C}$ aerobically for $24 \mathrm{~h}$. Inhibition zones were measured and recorded appropriately. If inhibition zones are found in the third well, the isolates were considered to be able to produce bacteriocin-like substance.

\subsubsection{Sensitivity of bacteriocin produced by LAB to proteinase}

To confirm production of a proteinaceous compound, cell-free supernatant displaying antimicrobial potential after acid neutralization and $\mathrm{H}_{2} \mathrm{O}_{2}$ elimination were treated with $1 \mathrm{mg}$ ml-1 of proteolytic enzymes, including Pepsin and Trypsin at $37{ }^{\circ} \mathrm{C}$ for $2 \mathrm{~h}[23 ; 24]$. Each enzyme is dissolved in plug phosphate buffer and sterilized by filtration ( $\left.0.2 \mu \mathrm{m}\right)$. Antimicrobial activity of treated culture broth was determined by the agar diffusion bioassay as described above.

\subsubsection{Thermal stability of bacteriocins produced by LAB isolates:}

Sensitivity of the bacteriocins to heat was investigated using a modified method of [25]. The $\mathrm{pH}-\mathrm{adjusted}$ and $\mathrm{H}_{2} \mathrm{O}_{2}$ eliminated cell-free supernatant described above were treated at $60^{\circ} \mathrm{C}, 90^{\circ} \mathrm{C}$ for 20 mins and at $121{ }^{\circ} \mathrm{C}$ for $15 \mathrm{mins}$. pH -adjusted and $\mathrm{H}_{2} \mathrm{O}_{2}$ - eliminated cell-free supernatant without any heat treatments served as control. Residual antimicrobial activity of heat-treated culture broth was determined by the agar diffusion bioassay.

\subsubsection{Effects of $\mathrm{pH}$ on the bacteriocins:}

In order to determine the sensitivity of the bacteriocins to $\mathrm{pH}$, a modified method of [25] was employed. The cell-free supernatant of each strain was adjusted to $\mathrm{pH}$ levels ranging from 2 to 10 (intervals of 2) with $\mathrm{HCl}$ and $\mathrm{NaOH}$, incubated at $37^{\circ} \mathrm{C}$ for $5 \mathrm{~h}$ and then tested for bacteriocin activity using the agar well diffusion assay. The supernatant of unadjusted $\mathrm{pH}$ served as controls.

\subsection{Production of a model cultured milk (Nono)}

The effect of in situ bacteriocin production on the behavior of Vibrio spp in Nono was determined during storage using a modified method of [26]. Fresh milk was aseptically collected from the teat of a cow and transported to the laboratory. The milk was pasteurised at $72^{\circ} \mathrm{C}$ for 20 minutes. After pasteurisation the milk was cooled to $40-45^{\circ} \mathrm{C}$. The milk was then inoculated with the bacteriocin producing $\mathrm{LAB}\left(1.5 \mathrm{X} 10^{8} \mathrm{cfu} / \mathrm{ml}\right)$ and stirred well for 3-5 minutes to ensure uniform distribution of starter culture. The milk was fermented at $30^{\circ} \mathrm{C}$ for a period of 24 hours. None inoculated milk served as control. The fermented milk was then artificially contaminated with Vibrio species $\left(1.5 \mathrm{X} 10^{6} \mathrm{cfu} / \mathrm{ml}\right)$. The food product was tested at selected intervals (12 h) for 72 hours for the presence or absence of Vibrio species. Counts of Vibrio species were performed on TCBS (Thiosulphate citrate bile salt sucrose) agar after incubation at $37^{\circ} \mathrm{C}$ for 48 hours. 


\section{Results}

A total of 112 LAB strains were isolated from fermented milk products and were initially screened for antagonistic activity against six Vibrio species (V. alginolyticus, $V$. parahaemolyticus, V. cholera, $V$. fluvialis, $V$. harveyi, $V$. vulnificus) by the agar well diffusion assay using cell free supernatant of broth culture (Table 1). Of the 112 strains tested, 13 produced bacteriocin that inhibited Vibrio spp. Subsequently, only twelve were selected based on their zone of inhibition for identification to species level.

Table 1 Antagonistic activity of LAB metabolites isolated from milk products against Vibrio species

\begin{tabular}{llllllllllllll}
\hline & \multicolumn{10}{c}{ Bacteriocin producing Lactic Acid Bacteria/Zone of Inhibition(mm) } \\
\hline Indicator organisms & $\mathbf{W 1 8}$ & $\mathbf{W 2 3}$ & $\mathbf{N 2 8}$ & $\mathbf{N 2 9}$ & $\mathbf{N 3 1}$ & $\mathbf{N 3 9}$ & $\mathbf{N 4 2}$ & $\mathbf{N 4 3}$ & $\mathbf{W 4 5}$ & $\mathbf{N 4 6}$ & $\mathbf{N 5 4}$ & $\mathbf{N 5 6}$ & $\mathbf{N 5 8}$ \\
\hline V. fluvialis & 17 & 17 & 14 & 15 & 15 & 18 & 15 & 16 & 16 & 14 & 15 & 17 & 18 \\
V. cholera & 16 & 16 & 16 & 16 & 16 & 15 & 18 & 14 & 14 & 15 & 13 & 13 & 15 \\
V. parahaemolyticus & 20 & 17 & 19 & 17 & 16 & 16 & 15 & 18 & 19 & 16 & 16 & 17 & 17 \\
V. vulnificus & 16 & 14 & 14 & 14 & 13 & 13 & 15 & 14 & 14 & 14 & 13 & 13 & 13 \\
V. alginolyticus & 18 & 14 & 14 & 14 & 13 & 12 & 13 & 14 & 14 & 13 & 14 & 14 & 14 \\
V. harveyi & 16 & 17 & 15 & 14 & 18 & 18 & 15 & 15 & 15 & 14 & 17 & 15 & 15 \\
\hline
\end{tabular}

All the LAB isolates were Gram positive, catalase negative, non-spores forming, non-motile, cocci and rods. Carbohydrate utilization pattern of the isolates was used to differentiate and identified the isolates to species level. The isolates were identified as Pediococcus damnosus, Pediococcus acidilactici, Lactobacillus brevis and Lactobacillus plantarum. The cell free supernatant of the 12 strains of LAB were treated with catalase, NaOH, proteolytic enzymes (trypsin and pepsin) and tested by the agar well diffusion assay against the Vibrio species as shown in Table 2. Catalase and $\mathrm{NaOH}$ had no effect on the inhibition, that is, the antimicrobial activity was still maintained, indicating that hydrogen peroxide and organic acids respectively did not account for the observed inhibition. However, the antimicrobial activity from all the strains was completely inactivated by treatment with trypsin and pepsin (Table 2).

Table 2 Effects of $\mathrm{NaOH}$, Catalase enzyme, Trypsin and Pepsin on the activity of bacteriocin produced by LAB

\begin{tabular}{|c|c|c|c|c|c|}
\hline Isolates & Untreated & $\mathrm{NaOH}$ & Catalase & Trypsin & Pepsin \\
\hline P. damnosus & + & + & + & - & - \\
\hline P. acidilactici & + & + & + & - & - \\
\hline L. brevis & + & + & + & - & - \\
\hline P. acidilactici & + & + & + & - & - \\
\hline L. brevis & + & + & + & - & - \\
\hline P. acidilactici & + & + & + & - & - \\
\hline L. plantarum & + & + & + & - & - \\
\hline L. plantarum & + & + & + & - & - \\
\hline L. plantarum & + & + & + & - & - \\
\hline L. plantarum & + & + & + & - & - \\
\hline L. plantarum & + & + & + & - & - \\
\hline L. plantarum & + & + & + & - & - \\
\hline P. damnosus & + & + & - & + & + \\
\hline
\end{tabular}


The bacteriocins produced by these isolates were heat-treated at $60^{\circ} \mathrm{C}, 90^{\circ} \mathrm{C}$ for 20 mins and at $121^{\circ} \mathrm{C}$ for 15 mins and were observed to be stable at $60^{\circ} \mathrm{C}-90^{\circ} \mathrm{C}$ conditions as indicated by their inhibitory effects against Vibrio species (Table 3).

Table 3 Thermal stability of the bacteriocin produced by LAB isolates

\begin{tabular}{lcccc}
\hline \multirow{2}{*}{ Isolates } & \multicolumn{4}{c}{ Temperature $\left({ }^{\circ} \mathbf{C}\right)$} \\
\cline { 2 - 5 } & Untreated & $\mathbf{6 0}$ & $\mathbf{9 0}$ & $\mathbf{1 2 1}$ \\
\hline P. damnosus & + & + & + & - \\
P. acidilactici & + & + & + & - \\
L. brevis & + & + & + & - \\
P. acidilactic & + & + & + & - \\
L. brevis & + & + & + & - \\
P. acidilactic & + & + & + & - \\
L. plantarum & + & + & + & - \\
L. plantarum & + & + & + & - \\
L. plantarum & + & + & + & - \\
L. plantarum & + & + & + & - \\
L. plantarum & + & + & + & - \\
L. plantarum & + & + & + & -
\end{tabular}

Stability of the bacteriocin was evaluated at different $\mathrm{pH}$ values ranging from 2 to 10 at $37^{\circ} \mathrm{C}$ for $5 \mathrm{~h}$, it was observed that the antimicrobial activity against Vibrio species was retained in $\mathrm{pH}$ ranges form 2-6, however the inhibitory activity was lost at alkaline $\mathrm{pH}$ (Table 4).

Table 4 Stability of bacteriocin produced by LAB isolates at different $\mathrm{pH}$

\begin{tabular}{|c|c|c|c|c|c|}
\hline Isolates & pH 2 & pH 4 & pH 6 & pH 8 & pH 10 \\
\hline P. damnosus & + & + & + & - & - \\
\hline P. acidilactici & + & + & + & - & - \\
\hline L. brevis & + & + & + & - & - \\
\hline P. acidilactici & + & + & + & - & - \\
\hline L. brevis & + & + & + & - & - \\
\hline P. acidilactici & + & + & + & - & - \\
\hline L. plantarum & + & + & + & - & - \\
\hline L. plantarum & + & + & + & - & - \\
\hline L. plantarum & + & + & + & - & - \\
\hline L. plantarum & + & + & + & - & - \\
\hline L. plantarum & + & + & + & - & - \\
\hline L. plantarum & + & + & + & - & - \\
\hline
\end{tabular}


The effect of in situ bacteriocin production on the survival of Vibrio spp in Nono was determined after fermentation during the storage period of 72 hours (12 hours interval). Figures 1a-d shows the survival of Vibrio species in Nono produced with bacteriocin-producing Pediococcus damnosus, Pediococcus acidilactici, Lactobacillus brevis and Lactobacillus plantarum respectively. It was observed that Vibrio species counts were reduced to different extents in all samples of Nono and undetetable within 48 to 60 hours of Nono storage. On the contrary, Vibrio species survived for 72 hours of storage in the control experiment that contained no bacteriocin-producing LAB.
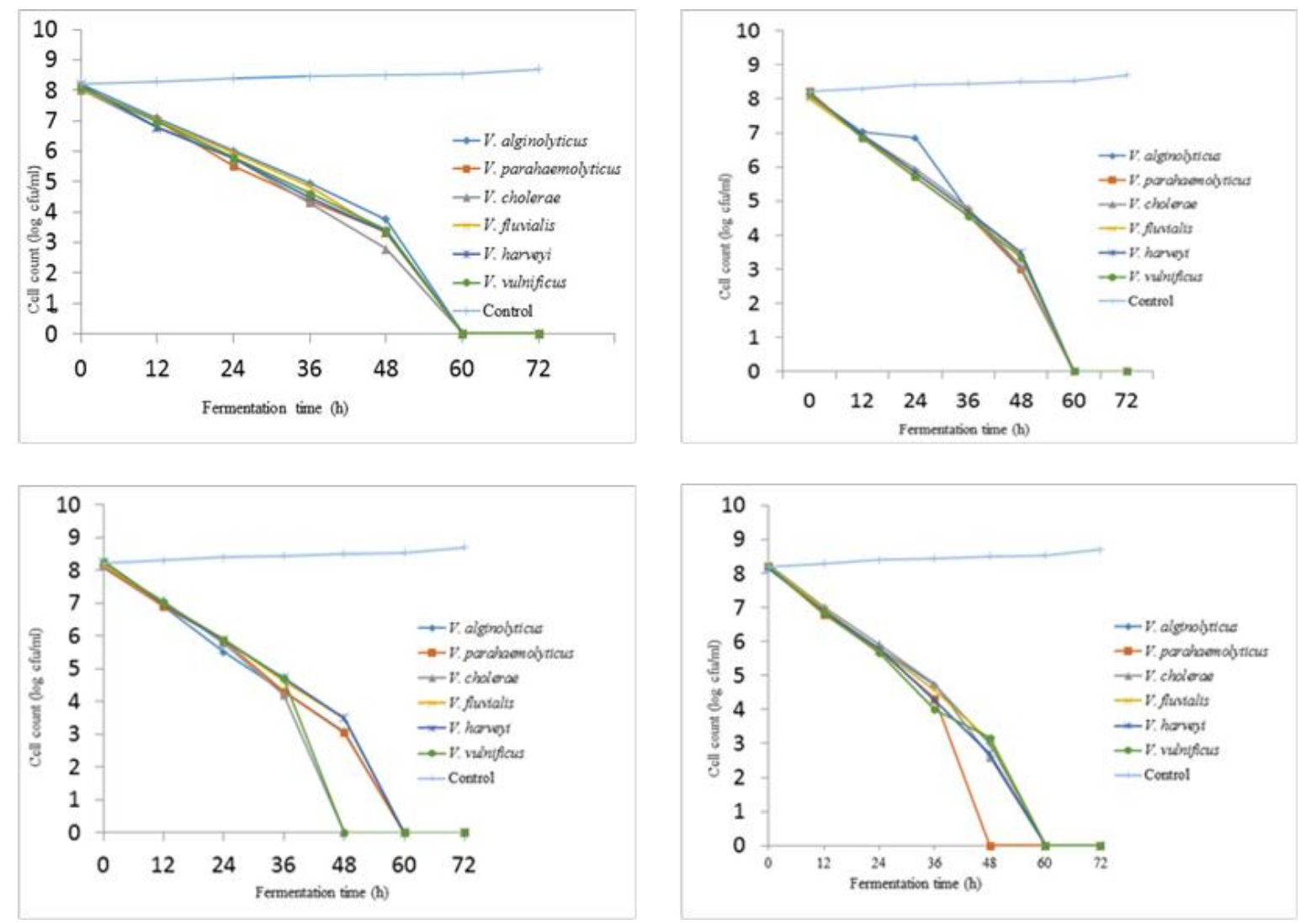

Figure 1 Survival of Vibrio spp. in Nono produced with bacteriocin-producing a- Pediococcus damnosus; b-Pediococcus acidilactici; c- Lactobacillus brevis; d- Lactobacillus plantarum

\section{Discussion}

This study was undertaken to demonstrate the antagonistic property of bacteriocin-producing Lactic acid bacteria on Vibrio cholera, Vibrio alginolyticus, Vibrio vulnificus, Vibrio parahaemolyticus, Vibrio harveyi, and Vibrio fluvialis in vitro and in situ

The fermented milk products (yoghurt, nono, wara) analyzed was found contained lactic acid bacteria (LAB) in different numbers. Nono had higher lactic acid bacteria counts than wara and yoghurt. This is in conformity with the report of [27] and [28] that in the locally fermented foods analyzed, nono had higher LAB count than wara, fufu and akamu. Phenotypic and biochemical identification of the twelve selected isolates were carried out.

A total of 112 LAB strains were isolated from fermented milk products and were initially screened for antagonistic activity against the Vibrio species by the agar well diffusion assay. Of the 112 strains tested, 13 produced an inhibition zone against the Vibrio spp. In this step, the possible inhibitory effect of the organic acids and hydrogen peroxide was not excluded. Subsequently, only twelve were selected by the large zone of inhibition for their identification at species level. The cell free supernatant of the 12 strains were treated with catalase, $\mathrm{NaOH}$, proteolytic enzymes (trypsin and pepsin) and tested by the agar well diffusion assay against the Vibrio spp. Catalase and Sodium hydroxide (NaOH) treatment of cell free supernatant had no effect on the inhibitory activity, that is, the antimicrobial activity was still maintained, indicating that hydrogen peroxide and organic acids did not account for the observed inhibition. However, the antimicrobial activity from all the strains was completely inactivated by treatment of the cell free supernatant with trypsin and pepsin. This confirms that the inhibition is as a result of a proteinacious compound and provides evidence 
that growth inhibition of the Vibrio species was caused by a bacteriocin. Bacteriocins have been reported to be inhibitory against several other bacteria $[11 ; 29 ; 30 ; 31 ; 25 ; 22]$.

Phenotypic, morphological and biochemical characterization of the LAB isolates identified the organisms as Pediococcus damnosus, Pediococcus acidilactici, Lactobacillus brevis and Lactobacillus plantarum. The characterization of these isolates agreed with Bergey's Manual of Systematic Bacteriology [20].

The bacteriocins produced by LAB isolates were observed to be stable at $60^{\circ} \mathrm{C}, 90^{\circ} \mathrm{C}$ for 20 mins but not at $121^{\circ} \mathrm{C}$ for 15 mins. This is in agreement with the work of Andersson [32] who reported the loss of bacteriocin activity after heating at $121^{\circ} \mathrm{C}$ for 10 mins. Also, Ogunbanwo et al. [11] recorded the loss of inhibitory activity of bacteriocin produced by L. plantarum at $121^{\circ} \mathrm{C}$ for 10 mins. The thermal stability of the bacteriocins produced by these LAB isolates may constitute an advantage for potential use as biopreservatives in combination with thermal processing in order to preserve food products [22]. This resistance is also known for other bacteriocin produced by lactic acid bacteria: lactacin B [33], lactacin F [34], nisin [35] and bacteriocin ST15 [36].

Bacteriocins were stable at different $\mathrm{pH}$ values ranging from 2 to 6 (intervals of 2 ) at $37^{\circ} \mathrm{C}$ for $5 \mathrm{~h}$, it was observed that the antimicrobial activity against Vibrio species was retained in $\mathrm{pH}$ range 2-6. However the inhibitory activity was lost at pH 8 and 10. This is in agreement with the work of Ogunbanwo et al. [11] who reported that the activity of bacteriocin elaborated by the test isolates was $\mathrm{pH}$ dependent and recorded that the highest antibacterial activity was exhibited in an acidic $\mathrm{pH}$ range of 2 to 6, while inactivation occurred at $\mathrm{pH} 8$ to 12. The work carried out by Lade et al. [37] also stated that bacteriocin were stable in acidic to neutral range i.e. from pH 4.0 to 7.0, but, inactive in the alkaline range. These data suggest that the bacteriocin described in this study could be applied in both low and medium-acidic food products with final $\mathrm{pH}$ values in such range; this includes a number of fermented and ripened dairy and meat products [25].

The effect of in situ bacteriocin production on the survival of Vibrio species in Nono was determined after fermentation during the storage period of 72 hours. It was observed that Vibrio species counts were reduced to different extents in all samples of Nono and undetetable within 48 to 60 hours in Nono produced with bacteriocin producing LAB during storage periods. On the contrary, Vibrio species survived for 72 hours of storage in the control experiment (unfermented milk) that contained no bacteriocin-producing LAB. This is in consonance with the work of Benkerroum et al. [38] that reported a significant decrease in the amount of L. monocytogenes in a $1-\mathrm{mL}$ sample within $24 \mathrm{~h}$ of storage at $7^{\circ} \mathrm{C}$ in lben fermented with the bacteriocin-producing starter culture. The work demonstrates that the use of selected bacteriocin-producing starter in milk fermentation might contribute to ensuring the safety of dairy products, especially when they are obtained from raw or minimally processed milk.

\section{Conclusion}

From the present study, bacteriocin-producing LAB were obtained from fermented milk products and were able to inhibit the growth of Vibrio species with multiple antibiotic drug resistance. The selected bacteriocin-producing LAB isolated from milk fermentation could be used to inhibit Vibrio species and act as biopreservation of milk and its products. Vibrio species have shown to be sensitive to the bacteriocin produced by LAB in vitro and in situ.

\section{Compliance with ethical standards}

\section{Acknowledgments}

The authors are grateful to the department of Microbiology University of Ibadan and the Department of medical Laboratory Science, Ogun State College of Health Technology, Ilese Ijebu for making available their facilities for usage.

\section{Disclosure of conflict of interest}

Authors declared that there is no conflict of interest.

\section{References}

[1] Michaela S, Reinhard W, Gerhard K and Christine ME. (2009). Cultivation of anaerobic and facultatively anaerobic bacteria from spacecraft-associated clean rooms. Applied and Environmental Microbiology, 11(75), 3484-3491. 
Ogunbanwo et al. / World Journal of Advanced Research and Reviews, 2020, 06(03), 050-058

[2] Axelsson L. (2004). Lactic Acid Bacteria: Classification and physiology. In: Lactic Acid Bacteria, Microbiological and Functional Aspects. Salminen, A.V. and A.O. Wright (Eds) ouwehand. Marcel Dekker, New York, 1-66.

[3] Whittenbury R. (1964). Hydrogen peroxide formation and catalase activity in the lactic acid bacteria. Journal of General Microbiology, 35, 13-26.

[4] Oladele AC, Deji-Agboola AM and Ogunbanwo ST. (2010). Antibacterial Activity of Lactic Acid Bacteria Isolated from Healthy Human Vagina Against Sexually Transmitted Disease Organisms. Ethiopian Pharmaceutical Journal, $28,1-11$.

[5] Salminen S, Von WA, Morelli L, Marteau P, Brassart D, de Vos WM, Fonden R, Saxelin M, Collins K., Mogensen G, Birkeland SE and Mattila-Sandholm T. (1998). Demonstration of safety of probiotics-a review. International Journal of Food Microbiology, 44, 93-106.

[6] Vandenbergh RA. (1993). Lactic acid bacteria, their metabolic products and interference with microbial growth. FEMS Microbiology Reviews, 12, 221-238.

[7] Bowdish DM, Davidson DJ and Hancock RE. (2005). A re-evaluation of the role of host defence peptides in mammalian immunity. Current Protein and Peptide Science, 6, 35-51.

[8] Diop MB, Dibois-Dauphin R, Tine E, Jacqueline ANand Thonart P. (2007). Bacteriocin producers from traditional food products. Biotechnology, Agronomy, Society and Environment, 11, 275-281.

[9] Ogunbanwo ST, Sanni AI and Onilude AA. (2003). Characterization of bacteriocin produced by Lactobacillus plantarum F1 and Lactobacillus brevis OG1. African Journal of Biotechnology, 2, 219-227.

[10] Nettles CG and Barefoot SF. (1993). Biochemical and genetic characteristics of bacteriocins of food associated lactic acid bacteria. Journal of Food Protection, 56, 338-356.

[11] Drake SL, Depaola A and Jaykus L. (2007). An Overview of Vibrio vulnificus and Vibrio parahaemolyticus. Comprehensive Reviews in Food Science, 6, 120-144.

[12] Sasaki S, Suzuki H, Igarashi K, Tambatamba B and Mulenga P. (2008). Spatial analysis of risk factor of cholera outbreak for 2003-2004 in a periurban area of Lusaka, Zambia. American Journal of Tropical Medicine and Hygiene, 79, 414-421.

[13] Huq A, Small EB, West PA, Huq MI, Rahman R and Colwell RR. (1983). Ecological relationships between Vibrio cholerae and planktonic crustacean copepods. Applied and Environmental Microbiology, 45, 275-283.

[14] Rabbani GH and Greenough WB. (1999). Food as a Vehicle of Transmission of Cholera. Journal of Diarrhoeal Diseases Research, 17(1), 1-9.

[15] Shapiro RL, Altekruse S, Hutwagner L, Bishop R, Hammond R, Wilson S, Ray B, Thompson S, Tauxe RV, Griffin PM and the Vibrio Working Group. (1998).The role of Gulf Coast oysters harvested in warmer months in Vibrio vulnificus infections in the United States, 1988-1996. Journal of Infectious Diseases, 178, 752-759.

[16] Abdullahi IO, Umoh VJ and Galadima M. (2004). Hazards associated with Kilishi preparation in Zaria, Nigeria. Nigeria Journal of Microbiology, 18(1-2), 338-345.

[17] Chigozie Oramadike and Samuel Temitope Ogunbanwo. (2014). Incidence of Vibrio species in seafood samples collected from Lagos Lagoon, Nigeria. American Journal of Food Science and Nutrition, 1(5), 76-82.

[18] Sneath PA, Mair NS, Sharpe ME and Holts JG. (1986). Bergey’s Manual Systematic Bacteriology, Vol. 2, Baltimore MD: Willam and Wilkins.

[19] Ogunbanwo ST, Oloketuyi SF and Adegoke CO. (2015). Potency of Bacteriocin Porduced by Enterococcus species isolated from Wara a Nigerian White Soft Unripened Cheese against Pathogenic Organisms Journal of Antimicrobials. Photon, 130, 382-390.

[20] Yang E, Fan Lihua F, Jiang Y, Doucette C and Fillmore S. (2012). Antimicrobial activity of bacteriocin-producing Lactic acid bacteria isolated from cheeses and yogurts. AMB express, 2, 48.

[21] Bonadè A, Murelli F, Vescovo M and Scolari G. (2001). Partial characterization of a bacteriocin produced by Lactobacillus helveticus. Letters in Applied Microbiology, 33, 153.

[22] Herreros MA, Sandoval H, González L, Castro JM, Fresno JM and Tornadijo ME. (2005). Antimicrobial activity and antibiotic resistance of lactic acid bacteria isolated from Armada cheese (a Spanish goats" milk cheese). Food Microbiology, 22, 455-459. 
[23] Khay E, Idaomar M, Castro L, Miguel P, Bernardez P F, Senhaji SN and Abrini J. (2011). Antimicrobial activities of bacteriocin-like substatnces produced by Lactic acid bacteria isolated from Moroccan dromedary milk. African Journal of Biotechnology, 10(51), 10447-10455.

[24] Adesokan IA, Odetoyinbo BB, Ekanola YA, Avanrenren RE and Fakorede S. (2011). Production of Nigerian Nono using Lactic Starter Cultures. Pakistan Journal of Nutrition, 10(3), 203-207.

[25] Odunfa SA. (1985). African fermented foods. In. B.J.B Wood, ed. Microbiology of Foods. London: EL Sevier, 155191.

[26] Oyeleke SB, Faruk AK, Oyewole OA and Nabara HY. (2006). Occurrence of lactic acid bacteria in some locally fermented food products sold in Minna markets. Nigerian Journal of Microbiology, 20(2), 927-930.

[27] Flythe MD and Russsell JB. (2004). The effect of $\mathrm{pH}$ and a bacteriocin (bovicinHC5) on Clostridium sporogenes MD1, a bacterium that has the ability to degrade amino acids in ensiled plant materials. FEMS Microbiology Ecology, 47, 215-222.

[28] Moghaddam MZ, Sattari M, Mobarez AM and Doctorzadeh F. (2006). Inhibitory effect of yogurt Lactobacilli bacteriocins on growth and verotoxins production of enterohemorrhgic Escherichia coli 0157:H7. Pakistan Journal of Biological Science, 9(11), 2112-2116.

[29] Karthikeyan V and Santosh SW. (2009). Isolation and partial characterization of bacteriocin produced from Lactobacillus plantarum. African Journal of Microbiology Research, 3(5), 233-239.

[30] Andersson R. (1986). Inhibition of Staphylococcus aureus and spheroplasts of gram-negative bacteria by antagonistic compound produced by a strain of Lactobacillus plantarum. International Journal of Food Microbiology, 3, 149-160.

[31] Barefoot SF and Klaenhammer TK. (1983). Detections and activity of lactacin B on bacteriocin produced by Lactobacillus acidophilus. Applied and Environmental Microbiology, 45, 1808-1815.

[32] Muriana PM and Klaenhammer TR. (1987). Conjugal transfer of pasmid-encoded determinants for bacteriocin production and immunity in Lactobacillus acidophilus 88. Applied and Environmental Microbiology, 53, 553-560.

[33] Bailey FJ and Hurst A. (1971). Preparation of a highly active form of nisin from Streptococcus lactis. Canadian Journal of Microbiology, 17, 61-67.

[34] De Kwaadsteniet M, Todorov SD, Knoetze H and Dicks LMT. (2005). Characterization of a 3944 Da bacteriocin, produced by Enterococcus mundtii ST15, with activity against Gram-positive and Gram-negative bacteria. International Journal of Food Microbiology, 105, 433-444.

[35] Lade HS, Chitanand MP, Gyananth G and Kadam TA. (2006). Studies on some properties of Bacteriocins produced by Lactobacillus species Isolated from Agro-Based waste. International Journal of Microbiology, 2(1), $1937-8289$.

[36] Benkerroum N, Ghouati Y, Ghalfi H, Elmejdoub T, Roblain D, Jacques P and Thonart P. (2002). Biocontrol of Listeria monocytogenes in a model cultured milk (lben) by in situ bacteriocin production from Lactococcus lactis ssp. Lactis. International Journal of Dairy Technology, 55, 145-151.

\section{How to cite this article}

Ogunbanwo ST, Odubanjo OR, Adegoke CO and Oramadike C. (2020). Bio-control of Vibrio species in cultured milk by in situ bacteriocin production from lactic acid bacteria. World Journal of Advanced Research and Reviews, 6(3), 50-58. 